\title{
Ozone induced cell death in HeLa cell culture mediated through stimulation of TNF-alpha
}

\begin{abstract}
Ozone has been in used as a therapeutic agent for the treatment of infective and inflammatory diseases, including cancer. The relationship of ozone with cancer and mechanism underlying the therapeutic effect of ozone on cancer remain unclear. This is first attempt to study the effect of ozone on cancer cells and how ozone induced cell death is mediated by activation of tumor necrosis factor (TNF)- $\alpha$ by using in vitro cell culture method. In the present study, HeLa cell cultures were subjected to ozone treatment at different dosages $(10,20,30 \& 40 \mu \mathrm{g} / \mathrm{ml})$. HeLa cells exhibited an increasing cell death with increase in ozone doses studied. A substantial enhancement of cell death was observed after 18 hours of ozone treatment onwards. Treatment with 30 and $40 \mu \mathrm{g} / \mathrm{ml}$ of ozone showed an elevated sensitivity to growth inhibition compared to the treatments 10 and $20 \mu \mathrm{g} / \mathrm{ml}$. Additionally cell detachment and cell floating were also faster and higher in ozone treatment with 30 and $40 \mu \mathrm{g} / \mathrm{ml}$. Tumor necrosis factor alpha (TNF- $\alpha$ ), is a multifunctional cytokine playing a key role in apoptosis and cell survival as well as in inflammation and immunity. Hence we also studied the release of TNF- $\alpha$ in response to various dosages of ozone-treatments by using ELISA technique. We found that TNF- $\alpha$, secretion was found to be enhanced with increase in cell death and at dose $40 \mu \mathrm{g} / \mathrm{ml}$ ozone treatment, cell death was highest and TNF- $\alpha$ secretion was also highest. Our study suggests that ozone induced cell death in HeLa cell lines is mediated through the activation of TNF- $\alpha$ pathway and the role of ozone in inducing apoptosis cannot be ruled out.
\end{abstract}

Keywords: cancer, ozone, HeLa cell, TNF- $\alpha$, In vitro culture
Volume 2 Issue 4 - 2015

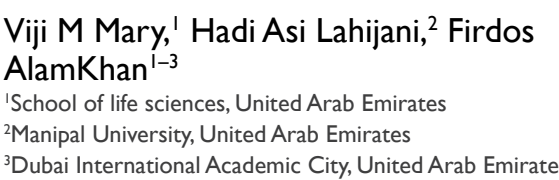

Correspondence: Firdos Alam Khan, School of Life Sciences, Manipal University Dubai, Dubai International Academic City, P.O.Box 345050 Dubai, United Arab Emirates, Tel 97|44290732, Email Firdoskhan1969@gmail.com

Received: August 29, 2014 | Published: June 05, 2015

\section{Introduction}

For many years ozone is used as a therapeutic agent for treatments of various pathological conditions. Now there are several thousand practitioners using ozone therapy worldwide. Some people, including a number of doctors and biochemists, believe Ozone has remarkable healing properties. ${ }^{1,2}$ Although ozone's medical value has been the subject of controversial and emotional debate, ${ }^{3}$ the medical benefits of ozone treatment have a long history as in the year 1892; The Lancet the Lancet published an article describing the administration of ozone for treatment of tuberculosis. In 1902, they published another article claiming success in treating chronic middle ear deafness with ozone ${ }^{4}$ and since then there has been few publications of ozone research by medical associations in English speaking countries..$^{5-7}$ In the beginning, much of the concern related to ozone therapy revolves around the safety of blood ozonation. It is well established that when inhaled by mammals, ozone reacts with compounds in tissues lining the lungs and triggers a cascade of physiological effects. As far as role of ozone in cancer treatment is concerned, there are quite a few investigations done which suggests that ozone has beneficial effects in cancer. In 1980 laboratory studies by main stream cancer researchers at Washington University discovered ozone inhibited growth of lung, breast, and uterine cancer cells in a dose dependent manner while healthy tissues were not damaged by ozone. ${ }^{8}$ Although these preliminary findings have long been argued justified funding for further research it should not be assumed that ozone would be similarly effective in vivo and could cure cancer. In 1990 pre-clinical French studies reported ozone enhanced the treatment of chemo resistant tumors and seemed to act adjunctively to chemotherapy in tumors derived from the colon and breast. ${ }^{9}$

Recent research by radiation and oncology researchers has shown ozone therapy can improve oxygenation in hypoxic tumors. ${ }^{10,11}$ In 2004
Oxford University reported that Spanish cancer research institutes conducted human trial using ozone involving 19 patients with incurable head and neck tumors and results suggested that ozone treated patients survived slightly longer than those receiving chemotherapy. ${ }^{10}$ There are reports that ozone may be useful in treating the debilitating side effects of orthodox cancer treatment. Radiation-induced injuries have been successfully treated with ozone application. ${ }^{11}$ Recent Cuban experiments on rats have shown that ozone treatment can alleviate the adverse effects of Cisplatin a popular modern anticancer drug that has been well documented to induce extreme toxicity and acute damage in the kidneys of animals and humans. ${ }^{12-14}$ Human trials at the Department of Oncology, Nizhni Novgorod State Medical in Russia also report benefits of complimentary ozone treatment with regard to drug complications..$^{14,15}$ In view of potential role of ozone in cancer treatment, we were interested to find out how ozone induced cell death in cancer cell line and is ozone effect is mediated through tumor necrosis factor (TNF) pathway. We started our work to study the effect of ozone on cancer cell using HeLa cell line as a research model. HeLa cell was grown and treated with various dosages of ozone and we studied cell death profile after ozone treatment and also analyzed the level of TNF- $\alpha$ secretion using ELISA technique.

\section{Materials and methods}

\section{Cell culture}

Human cervical carcinoma cell line, HeLa was kindly gifted by Dr. K. Satyamoorthy, Manipal University, India and cultured and maintained in tissue culture flasks containing DMEM (Dulbecco's Modified Eagle Medium) (supplied by Sigma) supplemented with $10 \% \mathrm{FBS}, 100 \mathrm{U} / \mathrm{ml}$ of antibiotic (penstrep), $0.25 \mu \mathrm{g} / \mathrm{ml}$ of fungizone (Amphotericin B ) and $2.5 \mathrm{mM} \mathrm{L}$-glutamine. The cultures were incubated in a humidified incubator with $5 \% \mathrm{CO} 2$ at $37^{\circ} \mathrm{C}$ to get 
confluent colonies. When the confluency reached to 70 to $80 \%$, cells were processed for sub culturing.

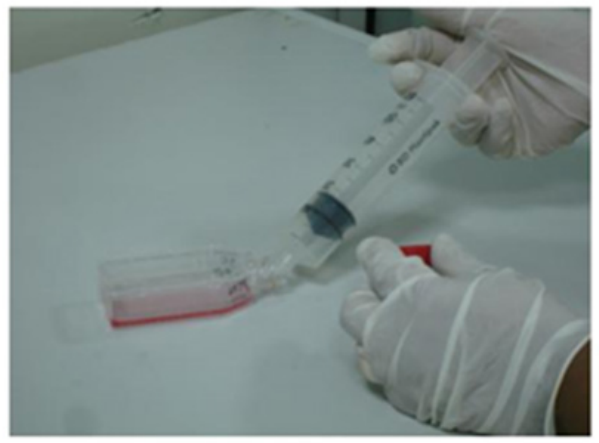

\section{Ozone treatment procedure}

Figure I Ozone treatment procedure:This picture shows a method of ozone treatment by placing culture flask horizontally under sterile condition.

\section{Subculturing of HeLa cells}

The culture flask with $70-80 \%$ confluent cells were trypsinized by fist washing with $1 \mathrm{x}$ PBS to remove any residual medium followed by $0.25 \%$ Trypsin-EDTA. Once the cells were removed from base, fresh media were added to the flask to neutralize enzyme activity. The cells were pelleted by centrifuging at $200 \mathrm{~g}$ for $5 \mathrm{~min}$. The spent medium was aspirated and the pellet was resuspended in the fresh culture medium and placed in the $\mathrm{CO} 2$ incubator at $37^{\circ} \mathrm{C}$ for growth and expansion.

\section{Preparation and measurement of medical ozone}

Ozone used in this study was generated from medical-grade oxygen using electrical corona arc discharge by using Ozone Generator provided by Rashid Hospital, Dubai, UAE, which allows the gas flow rate and Ozone concentration to be controlled as per the Standardization Committee of the International ozone Association. Medical ozone, which was produced in different concentrations (10, $20,30, \& 40 \mu \mathrm{g} / \mathrm{ml})$, was used to treat the cells by using polypropylene syringes (ozone-resistant).

\section{Ozone treatment to HeLa cells}

Under sterile condition, culture flask containing HeLa cells were, subjected to different ozone treatments with $10,20,30 \& 40 \mu \mathrm{g} / \mathrm{ml}$. The flasks were placed in horizontal position as shown in picture Figure 1 during injection of ozone. This method of ozone treatment avoided cells from direct expose to ozone. Control flasks were also maintained and used for the study. After ozone treatment the culture flasks were transferred to $\mathrm{CO} 2$ incubator and maintained at $37^{\circ} \mathrm{C}$. The effect of ozone was observed at different time intervals $(0 \mathrm{hr}, 6 \mathrm{hr}$, $18 \mathrm{hr}, 24 \mathrm{hr}, 30 \mathrm{hr}, 42 \mathrm{hr} \& 48 \mathrm{hr}$ ) post ozone treatments. The flasks were observed under inverted microscope (LABOMED, TCM400, USA) at 10x magnification and the total number of live cells and dead cells were counted by dye exclusion method with trypan blue using hemocytometer.

\section{Dye exclusion method of cell counting}

In order to check the viability of cells after ozone treatments, cells were stained with $0.4 \%$ Trypan blue. In brief, $10 \mu 1$ of this typan blue containing cells was applied to a hemocytometer chamber (Marienfeld, Germany), the viable (unstained), and non-viable (stained) cells were counted under microscope. The trypan blue was able to cross the cell membrane of dead cells and hence the non-viable cells appeared colored. In the viable cells only selective compounds cross the membrane barrier and hence they appeared colorless or unstained. The percentage viability was calculated by using this formula:

\section{Quantification of TNF- $\alpha$ secretion by ELISA}

With a view to study release of TNF- $\alpha$ secretion in the cells treated with ozone, we used anti human TNF- $\alpha$ antibody and quantified the amount of TNF- $\alpha$ secreted by the cells by using a commercially available ELISA kit (Endogen). The estimation of TNF- $\alpha$ was carried out as per the manufacturer's protocol. Briefly, $50 \mu \mathrm{l}$ of standard or sample was loaded to the wells in ELISA plate in duplicates and the plate was incubated at room temperature for $1 \mathrm{hr}$. The plate was washed three times with buffer provided in the kit and incubated with primary antibody for $1 \mathrm{hr}$ at room temperature.

The plate was then washed three times with buffer and treated with Streptavidin-HRP reagent, and incubated at room temperature for 30 minutes. After washing with buffer, TMB substrate solution $100 \mu 1$ was added to each well and the plate was kept in dark at room temperature for 30 minutes. The reaction was stopped by adding stop solution. The plate was read in ELISA Reader using absorbance at $450 \mathrm{~nm}$ and $550 \mathrm{~nm}$. The standard curve was generated by plotting the average absorbance $(450 \mathrm{~nm}$ minus $550 \mathrm{~nm})$ obtained for each standard concentration versus the corresponding TNF- $\alpha$ concentration. The results were calculated using graph paper. The amount of TNF- $\alpha$ secreted in each sample was determined by interpolating from the TNF- $\alpha$ concentration ( $\mathrm{X}$ axis) to the absorbance value (Y axis).

\section{Results}

\section{Effect of ozone on cell death}

The effect of different dosages of ozone treatment on cell death percentage of HeLa cells over a period of time $(0,6,18,24,30,42$, \& 48 hours after treatment) is reported in Figure 2. At dose $10 \mu \mathrm{g} / \mathrm{ml}$ we did not find significant cell death initially, but subsequent cell death reached to $15.2 \%$ after 6 hours post-treatment and finally reaches to $37.8 \%$ after $48 \mathrm{hr}$ post-treatment. At dose $20 \mu \mathrm{g} / \mathrm{ml}$, the cell death increased by $37.5 \%$ after $24 \mathrm{hr}$ and reached to $51.5 \%$ after $48 \mathrm{hr}$ post ozone treatment. At $30 \mu \mathrm{g} / \mathrm{ml}$, cell death increased to $41 \%$ after $24 \mathrm{hr}$, reached to $74.2 \%$ after $48 \mathrm{hr}$ post ozone treatment. At $40 \mu \mathrm{g} / \mathrm{ml}$, the cell death was profoundly increased to $76 \%$ after $24 \mathrm{hr}$ and reached to $93.3 \%$ after $48 \mathrm{hr}$ post ozone treatment. The average cell death recorded in control or untreated cells was $8.8 \%$ after $42 \mathrm{hr}$ and $14.5 \%$ after $48 \mathrm{hr}$.

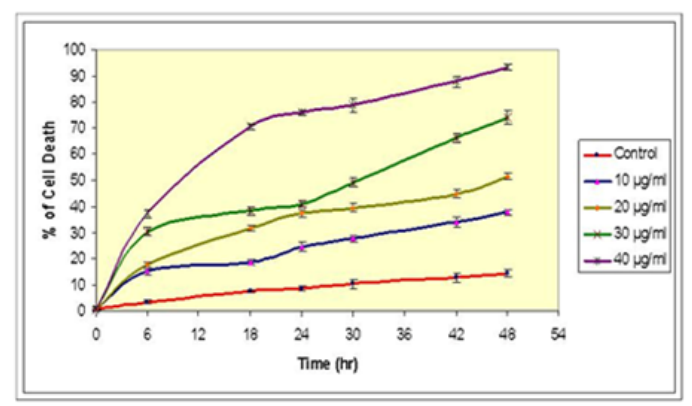

Figure 2 Effect of ozone concentration on cell death (\%) of HeLa cells: This graph shows cell death $\%$ quantified at different time intervals $(0,6,18,24$, 30,42 , and $48 \mathrm{hr}$ ) post ozone-treatments. Treatments include a control (no ozone treatment) 10,20,30 and $40 \mu \mathrm{g} / \mathrm{ml}$ of ozone. The values shown are representatives of two independent experiments. Points, mean; bars. 


\section{Morphological analysis}

The morphological changes due to ozone treatment which include cell size, cell abnormality, cell shrinkages, nuclear disintegration, and cell detachment were analyzed under microscope. In control or untreated cells, the cells appeared healthy with no changes in cytoplasm and nucleus Figure $3 \mathrm{~A}$, whereas at $10 \mu \mathrm{g} / \mathrm{ml}$ ozone treatments, the cells were found normal with slightly higher numbers of dead cells compared to control. No significant morphological changes could be detected either at the cytoplasmic or at the nuclear level Figure 3B. At $20 \mu \mathrm{g} / \mathrm{ml}$ ozone treatments, the cell death was found to be significantly higher than $10 \mu \mathrm{g} / \mathrm{ml}$ and dead cells were detached and floating on surface Figure 3C. At $30 \mu \mathrm{g} / \mathrm{lit}$ ozone treatment, the cells death were found to be higher than $10 \& 20 \mu \mathrm{g} / \mathrm{ml}$ concentration Figure 3D. More dead cells were found floating on the surface where as the live cells was found still attached to bottom. Interestingly, nuclear content was found to be reduced in almost all the cells when compared to the control. At $40 \mu \mathrm{g} / \mathrm{ml}$ ozone treatment, more than $90 \%$ of cells were found to be dead within 48 hours and it was clearly seen that the cells were shrunk and started floating in the media Figure $3 \mathrm{E}$.
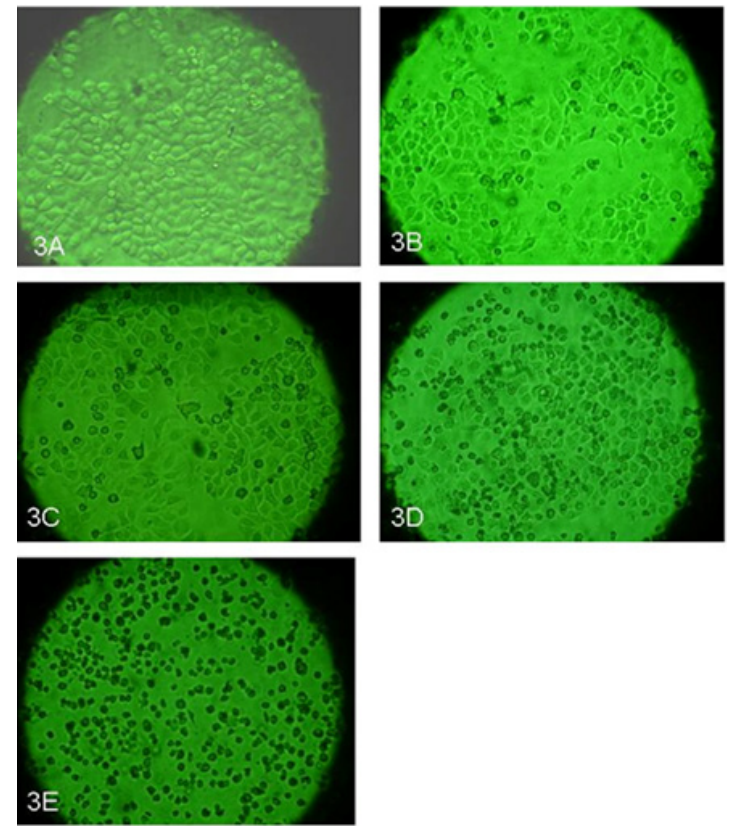

Figure 3 A-E. Morphology of the cells after ozone treatments:These pictures show the effect of ozone at various dose concentrations from 10,20,30 and $40 \mu \mathrm{g} / \mathrm{ml}$ of ozone after $48 \mathrm{hr}$ post treatment. Picture $3 \mathrm{~A}$ is control with no ozone treatment, picture $3 \mathrm{~B}$ shows cells treated with $10 \mu \mathrm{g} / \mathrm{ml}$; picture $3 \mathrm{C}$ shows cells treated with $20 \mu \mathrm{g} / \mathrm{ml}$; picture 3D shows cells treated with $30 \mu \mathrm{g} /$ $\mathrm{ml}$; and picture $3 \mathrm{E}$ shows cells treated with $40 \mu \mathrm{g} / \mathrm{ml}$. The pictures were taken at IOX magnification.

\section{Effect of ozone on TNF- $\alpha$ secretion}

This experiment was performed to determine whether the cytokine TNF- $\alpha$ is secreted by HeLa cell cultures in response to various dosages of ozone treatment and also to find out relationship between ozone induced cell death by TNF- $\alpha$ secretion. The secretion of TNF- $\alpha$ was analyzed by ELISA technique after $48 \mathrm{hr}$ post treatments with different dosages. At $10 \mu \mathrm{g} / \mathrm{ml}$, TNF- $\alpha$ level was $26 \mathrm{ug} / \mathrm{ml}$ compared to control which was $7.10 \mathrm{ug} / \mathrm{ml}$, whereas TNF- $\alpha$ increased to 35.1 $\mathrm{ug} / \mathrm{ml}$ after $20 \mathrm{ug} / \mathrm{ml}$ ozone treatment. At $30 \mathrm{ug} / \mathrm{ml}$ ozone treatment, TNF- $\alpha$ level significantly increased to $49.2 \mathrm{ug} / \mathrm{ml}$ and after $40 \mathrm{ug} / \mathrm{ml}$ ozone treatments, the amount of TNF- $\alpha$ level was $57.10 \mathrm{ug} / \mathrm{ml}$ Figure 4.

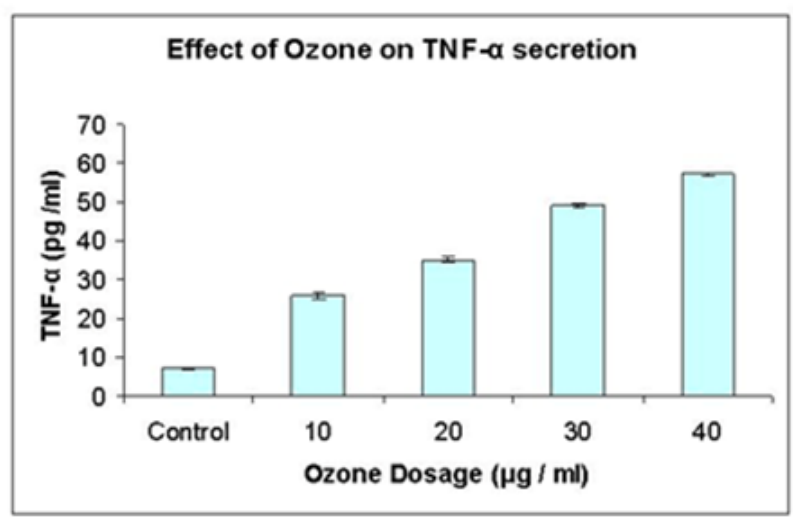

Figure 4 The effect of ozone on TNF- $\alpha$ secretion: This graph shows TNF- $\alpha$ secretion measured by ELISA method taken at different concentrations from 10, 20, 30 and $40 \mu \mathrm{g} / \mathrm{ml}$ of ozone. Control is with no ozone treatment. The values shown are representatives of two independent experiments. Points, mean; bars; SE.

\section{Discussion}

This is the first report which suggests that ozone can induce cell death in cancer cells in dose manner, while $10 \mathrm{ug} / \mathrm{ml}$ of ozone treatment showed $14.5 \%$ cell death and $40 \mathrm{ug} / \mathrm{ml}$ dose $93.3 \%$ cell death. The ozone-induced cell death mediated through activation through TNF- $\alpha$ pathway. In the present study we have observed a dose-dependent cell death in HeLa cells treated with ozone. The highest level of cell death (74.2\% and $93.3 \%$ ) was observed at dose $30 \mathrm{ug} / \mathrm{ml}$ and $40 \mathrm{mg} / \mathrm{ml}$ respectively whereas $10 \mathrm{ug} / \mathrm{ml}$ and $20 \mathrm{ug} / \mathrm{ml}$ showed $37.5 \%$ and $51.5 \%$ cell death respectively. We did not see significant change in cell death in control culture which is not treated with ozone. Similar kind of response was observed in human cancer cell treated with ozone where treatment of ozone caused $40-60 \%$ cell death. ${ }^{8}$

The untreated HeLa cells showed normal growth and development during culture, whereas HeLa cells treated with ozone showed a gradual cell death followed by a greater increase in cell death over a period of time. Treatment with 30 and $40 \mu \mathrm{g} / \mathrm{ml}$ of ozone treatment showed an elevated sensitivity to growth inhibition compared to the treatments 10 and $20 \mu \mathrm{g} / \mathrm{ml}$ respectively. Additionally cell detachment and cell floating were also faster and higher in ozone treatments 30 and $40 \mu \mathrm{g} / \mathrm{ml}$. However, the cell detachment and cell floating were noted significant from $6 \mathrm{hrs}$ after treatment onwards and reached maximum at $48 \mathrm{hrs}$ after treatment. In 1980 laboratory studies by main stream cancer researchers at Washington University discovered that the growth of human cancer cells from lung, breast, and uterine tumors was selectively inhibited in a dose-dependent manner by ozone at 0.3 to 0.8 part per million of ozone in ambient air during 8 days of culture. Human lung diploid fibroblasts served as noncancerous control cells. ${ }^{8}$ In 1990 pre-clinical French studies reported ozone enhanced the treatment of chemo resistant tumors and seemed to act adjunctively to chemotherapy in tumors derived from the colon and breast. ${ }^{9}$ On in- vitro investigations, ozone was found to act with specific cytostatics (5-Fluoruracil) in a synergistic and additive way in their ability to inhibit the growth of mammary and colonic carcinoma cells, i.e., on a tumor cell line and on primary tumor cells in humans.

We also observed dose-dependent increase in TNF- $\alpha$ secretion in response to ozone treatment. After $48 \mathrm{hr}$ post ozone treatment, we observed many fold increase in TNF- $\alpha$ secretion and clearly showed 
that ozone induced cell death may be mediated through activation of TNF- $\alpha$ pathway. Although there is no direct proof of role of ozone in TNF mediating cell death, it would be interesting to study the effect of ozone by using specific TNF- antagonistic receptors. We may suggest that ozone may be inducing its action through TNF- $\alpha$ receptors and causing programmed cell death. There is a report which suggests that ozone influence the release of interleukins (Type IL-1ß, 2, 4, 6, 8, 10), tumor necrosis factor (TNF- $\alpha$ ) and interferon (IFN- $\beta$, IFN-?) under in -vitro conditions on white cells in the peripheral blood. ${ }^{16}$ It would be interesting to examine the role of these cytokines in cancer cells after treating with ozone.

Our results suggest that there is a strong relationship between ozone-induced cell deaths in cancer cells with activation of TNF- $\alpha$ pathway, we speculate that ozone-treatment elevated the expression and synthesis of TNF- $\alpha$ which in turn induced apoptosis in the cancer cell lead to enormous cell death. A better understanding of the transcriptional activation involved in ozone treatment in the expression of the proinflammatory cytokines will be needed to determine the potential role of these cytokines in pathogenesis and to determine the effect of ozone on cancer cells. However, there were several previous reports suggesting the possible association between cervical cancer risk and the polymorphism of other cytokines or cytokine receptors, such as interleukin 10, and interleukin 1 receptor antagonist. ${ }^{17}$ Therefore, it can be speculated that functional variation of inflammatory cytokine may influence the individual susceptibility of cervical cancer. Degradation of the $p 53$ gene by oncogenic HPV E6 protein is the most well known carcinogenic mechanism in human cervical cancer. Interestingly, ozone was found to act with specific cytostatics (5-Fluoruracil) in a synergistic and additive way in their ability to inhibit the growth of mammary and colonic carcinoma cells, i.e. on a tumor cell line and on primary tumor cells in humans. ${ }^{9}$

It has been argued that ozone is not a correct therapeutic approach largely due to lack of understanding about its physiological action but ozone treatment as a therapy is a well established alternative and complementary therapy in most of the mainland European countries where health authorities have allowed its practice. In the early 1980's a German survey and investigation into ozone therapy by the University Klinikum in Giessen and the Institute for Medical Statistics, published in the Empirical Medical Acts revealed that over 5 million ozone treatments had been delivered to some 350,000 patients, by more than 1000 therapists and of this number about half were medical doctors. ${ }^{18}$ Although ozone is used in a complementary capacity by a significant number of doctors in Italy, Switzerland, Austria and Germany it has still not gained popular support with main stream industry policy makers in those countries. It is not covered by health insurance, nor is it part of the curriculum at most esteemed medical schools. In general countries with more socialist style health systems seem to have had less difficulty in accepting ozone as a medicine. ${ }^{19-23}$ However the use of ozone as therapy is evident in Bulgaria, Cuba, Czech Republic, France, Germany, Greece, Israel, Italy, Japan, Malaysia, Mexico, Poland, Romania, Russia, Switzerland, Turkey, United Arab Emirates, and Ukraine. In USA, recently passed Alternative Therapy Legislation has made ozone therapy an option for patients in some states. In Alaska, Arizona, Colorado, Georgia, Minnesota, New York, New Jersey, North Carolina, Ohio, Oklahoma, Oregon, South Carolina, and Washington Physicians can legally use ozone treatments in their practice without fear of prosecution.

\section{Conclusion}

We suggest that ozone caused cell death in the HeLa cell line in dose-dependent manner is physiological phenomenon and more research is required to understand its molecular action by mapping tumor suppressor gene and genes involved in the apoptotic pathway. The ozone-induced cell death in HeLa cell line is mediated through the activation of TNF- $\alpha$ is also indicating that there is a strong relationship between ozone and TNF in inducing programmed cell death in the cancer cells; however, more research is required to prove that ozone is indeed a therapeutic agent.

\section{Acknowledgements}

None.

\section{Conflicts on interest}

The authors declare that there have no conflicts of interest.

\section{Funding}

None.

\section{References}

1. Tylicki L, Rutkowski B. Ozone therapy seems to be safe, but is it really clinically effective? Int J Artif Organs. 2004;27(8):731-732.

2. Rilling S, Veibahn R. The use of ozone in medicine Haug New York. 1987.

3. Dianzani, F. The dilemma of exposing or burying a complementary medical approach. J Biol Regul Homeost Agents. 1996;10(2-3):29.

4. Stoker G. Ozone in chronic middle ear deafness. Lancet. 1902;11871188.

5. Quain JR. Ozone treatment of wounds. Lancet. 1940;1(6092):10281029.

6. Thwaites M. Ozone healing. Med J. 1977;1(20):757-758.

7. Baggs AC. Are worry-free transfusions just a whiff of ozone away? CMAJ. 1993;148(7):1155-1160.

8. Sweet F, Kao MS, Lee SC, et al. Ozone selectively inhibits growth of human cancer cells. Science. 1980;209(4459):931-933.

9. Zanker KS, Kroczek R. In vitro synergistic activity of 5-fluorouracil with low-dose ozone against a chemo resistant tumor cell line and fresh human tumor cells. Chemotherapy. 1990;36(2):147-154.

10. Clavo B, Pérez JL, López L, et al. Ozone therapy for tumor oxygenation: a pilot study. Evid Based Complement Alternat Med. 2004;1(1):93-98.

11. Clavo, B, Gutierrez D, Martín D, et al. Intravesical ozone therapy for progressive radiation induced hematuria. J Altern Complement Med. 2005;11(3):539-541.

12. Borrego A, Zullyt BZ, González R, et al. Protection by ozone preconditioning is mediated by the antioxidant system in cisplatininduced nephrotoxicity in rats. Mediators Inflamm. 2004;13(1):13-19.

13. Gretchkanev, et al. Role of ozone therapy in prevention and treatment of complications of drug therapy for ovarian cancer. Akusherstvo Ginekologiya. 2002;4:57-58.

14. Borrego A, Zamora ZB, González R, et al. Ozone/oxygen mixture modifies the sub cellular redistribution of Box protein in renal tissue from rats treated with cisplatin. Arch Med Res. 2006;37(6):717-722.

15. Bocci V, Luzzi E, Corradeschi F, et al. Studies on the biological effects of ozone: 5. Evaluation of immunological parameters and tolerability in normal volunteers receiving ambulatory autohaemotherapy. Biotherapy. 1993;7(2):83-90.

16. Bocci V, Alessandra L, Micheli V. Restoration of normoxia by ozone therapy may control neoplastic growth: a review and a working hypothesis. The Journal of Alternative and Complementary Medicine. 2005;11(2):257-265. 
17. Stanczuk GA, Sibanda EN, Tswana SA, et al. Polymorphism at the -308-promoter position of the tumor necrosis factor-alpha (TNF-alpha) gene and cervical cancer. Int J Gynecol Cancer. 2013;13(2):148-153.

18. Jacobs. Untersuchung über zwischenfalle und typische komplikationen in der ozon-sauerstoff-therapie. Ozo Nachrichten. 1982;1:5.

19. Ikonomidis. New data regarding the use of ozone therapy in the former Soviet union countries. Rivista Italiana di Ossigeno-Ozonoterapia. 2005;4(1):40-43.

20. Madej P, Antoszewski Z, Madej JA. Ozonotherapy. Mater Med Pol. $1995 ; 27(2): 53-56$.
21. González R, Borrego A, Zamora Z, et al. Reversion by ozone treatment of acute nephrotoxicity induced by cisplatin in rats. Mediators Inflamm. 2004;13(5-6):307-312.

22. The internal administration of ozone in the treatment of Phthisis. Lancet. 1982;II:1180-1181.

23. Potanin. Ozonotherapy in the early postoperative period in the surgical treatment of the lung cancer. [Written in Russian] Kazanskij Medicinskij Zurnal. 2000;263-265. 